\title{
UJI DAYA ANTIBAKTERI SARI PATI DAUN RUKAM (Flacourtia rukam) TERHADAP ZONA HAMBAT Escherichia coli
}

Desmi Viana Putri ${ }^{*}$, Fitria Lestari², Mareta Widiya ${ }^{3}$

1,2,3 STKIP PGRI Lubuklinggau, Jl. Mayor Toha Kel. Air Kuti, Lubuklinggau 31626, Indonesia

*Corresponding author, e-mail: desmivianaputri@gmail.com

\section{ABSTRACT}

Escherichia coli is a microscopic gram-negative bacteria that in the human digestive system and is one of the causes oof diarrheal disease. Treatment of dearrheal diseases usually uses chemical drugs. Chemical drugs are believed to have excessiive side effects. This can be replaced with a drug that has a low side effect in the from of traditional medicine. One plant that can be used as a medicine for diarrhea is rukam (Flacourtia rukam). Rukam (Flacourtia rukam) is a plant that has properties as an antibacterial drug. The compounds contained in rukam (Flacourtia rukam) include flavanoids, saponins, tannins, and alkaloids. The aim of this study was to determine the antibacterial strength of the extract of rukam (Flacourtia rukam) leaf starch againt the Escherichia coli inhibition zone. The results obtained that rukam (Flacourtia rukam) has a different inhibitory zone, from various concentrations of $4 \%, 6 \%, 8 \%, 10 \%$. Concentration with the highest inhibition zone is a concentration of $10 \%$.

Keywords: Leaves Rukam, Escherichia coli, Inhibition Zone

\section{PENDAHULUAN}

Indonesia merupakan salah satu negara yang memiliki permasalahan dalam tingkat kesehatan, salah satu permasalahan kesehatan saat ini terjadi pada balita dan bayi, suatu penyakit yang menjadi tingkat permasalahan terbesar di Indonesia yaitu diare (Rencana Aksi Program Pengendalian Penyakit \& Penyehatan Lingkungan, 2015). Bukan hanya Indonesia, Lubuklinggau juga mengalami permasalahan kesehatan mengenai diare. Data Dinas kesehatan Lubuklinggau (2017) menyatakan bahwa angka kesakitan diare mencapai per 1000 penduduk adalah sebanyak 214 . Pada tahun 2017 terdata 102 pasien yang terserang penyakit diare mulai dari anakanak hingga dewasa. Hal tersebut terlihat dari jumlah pasien yang dirawat di Rumah Sakit Siti Aisyah Lubuklinggau.

Penyakit diare merupakan penyakit yang banyak menyerang anak-anak dan dewasa serta menjadi salah satu penyakit menyebabkan kematian nomor 2 pada balita, penyebab kematian nomor 3 pada bayi dan hingga penyebab kematian nomor 5 pada semua umur (Selviana \& Widowati, 2015). Penyakit diare merupakan penyakit yang ditandai dengan adanya cairan yang berlebihan saat buang air besar. Sehingga dapat mengurangi cairan yang ada di dalam tubuh, penyakit diare ini juga merupakan salah satu penyakit yang dapat menular (Mafazah, 2013).

Selain itu dari hasil laporan Ehra (2013) manyatakan bahwa penyakit diare banyak terjadi pada musim hujan. Penyakit diare terjadi dengan adanya beberapa faktor. Salah satu adanya faktor penyebab diare adalah bakteri. Bakteri yang menyerang biasanya jenis bakteri Escherichia coli. Bakteri Escherichia coli merupakan salah satu bakteri gram negatif yang berukuran mikroskopik. Escherichia coli ini juga merupakan suatu bakteri yang hidup dalam sistem pencernaan. Namun, bila dalam 
kondisi yang berlebihan dapat bersifat patogen. Sembiring \& Nurhayati (2013) menjelaskan bahwa gejala seseorang yang mengalami penyakit diare yaitu muntah, mual, dehidrasi, lemah, pucat, seringnya buang air besar dan lain-lain. Penyakit diare masih bisa ditangani dengan berbagai macam obat. Salah satunya yaitu menggunakan obat sintetik atau obat kimia.

Obat kimia merupakan salah satu obat yang biasa dikonsumsi oleh masyarakat karena memiliki kelebihan dapat dibawa dan tidak melalui proses yang lama saat meminumnya. Obat kimia yang sering dipakai dalam pengobatan penyakit diare ialah oralit, pediyalite, renalyte dan lain-lain (Korompis, dkk, 2013) serta adanya tambahan tablet Zinc (Departemen Kesehatan RI, 2011). Penggunaan obat kimia memiliki kelemahan dapat menyebabkan efek samping yang berlebihan. Untuk itu obat kimia dapat digantikan dengan obat yang memiliki kelebihan efek samping yang sangat rendah. Salah satu obat yang memiliki efek samping yang rendah yaitu obat tradisional (Jennifer \& Saptutyningsih, 2015). Obat tradisional merupakan suatu obat yang sudah digunakan sejak zaman dahulu dan dilakukan secara turun temurun (Jennifer \& Saptutyningsih, 2015). Salah satu daerah yang terdapat banyak sekali obat tradisional serta masih mengkonsumsi obat tradisional yaitu daerah Kabupaten Musi Rawas.

Kabupaten Musi Rawas merupakan salah satu daerah yang terdapat di Sumatera Selatan. Kabupaten Musi Rawas memiliki banyak sekali tumbuhan obat yang bermanfaat dalam pengobatan tradisional khususnya dalam mengobati penyakit diare. Salah satu tumbuhan yang berpotensi sebagai obat diare yaitu rukam (Flacourtia rukam). Tumbuhan Flacourtia rukam merupakan suatu tumbuhan yang sangat unik. Karena, bila saat memakan buah Flacourtia rukam harus dipijit-pijit terlebih dahulu untuk menghilangkan rasa masam.

Berdasarkan hasil wawancara yang telah dilakukan diketahui bahwa masyarakat Kabupaten Musi Rawas telah mengenal Flacourtia rukam sebagai obat tradisional. Beberapa masyarakat menggunakan Flacourtia rukam sebagai obat obat sakit mata. Namun bila mengkonsumsi Flacourtia rukams ecara berlebihan dapat menimbulkan iritasi bahkan sampai buta.

Bagian rukam yang digunakan sebagai obat diare adalah bagian daun. Daun yang digunakan yaitu daun yang muda bewarna cerah. Daun Flacourtia rukam mengandung senyawa alkaloid, flavonoid, fenolik dan saponin (Fitri, dkk, 2016). Beberapa senyawa alkaloid berkhasiat sebagai antibakteri dan antidiare (Ningrum, dkk, 2016). Ikram et al (2009), melaporkan bahwa buah rukam memiliki kandungan fenolik lebih tinggi dibandingkan buah jambu biji (Psidium guajava).Senyawa flavonoid pada rukam menunjukan aktivitas antibakteri dengan merusak dinding sel dan membran sel bakteri (Yunikawati, dkk, 2013). Sedangkan senyawa saponin berfungsi sebagai menghambat produksi luka yang berlebihan.

Hasil uji coba pendahuluan yang telah dilakukan didapat bahwa sari pati daun rukam lebih baik dan terdapat zona bening dibandingkan daun yang dijadikan serbuk. Data uji pendahuluan dengan konsentrasi 3\% dapat menghambat bakteri Escherichia coli. Untuk itu perlu adanya pengujian daya antibakteri sari pati daun Flacourtia rukam terhadap zona hambat Escherichia coli.

\section{METODE}

Penelitian ini menggunakan metode eksperimental laboratorium (true eksperimental design) dengan rancangan penelitian post test only control group design. Jenis penelitian ini yaitu kuantitatif menggunakan yang bersifat angka atau bisa juga 
data yang bukan angka namun bisa dikuantitatifkan (Indrawan \& Yaniawati, 2014). Variabel bebas pada penelitian ini adalah daya antibakteri sari pati daun rukam. Variabel terikat pada penelitian ini adalah Eschericia coli. Penelitian ini menggunakan konsentrasi sari pati Flacourtia rukam sebanyak 4\%, 6\%, 8\%, 10\% yang telah dicampur dengan aquades dan di setiap perlakuan terdiri atas 5 pengulangan. Kontrol positif pada penelitian ini menggunakan obat antibiotik ampicilin. Parameter yang akan diukur yaitu daya hambat ataupun zona bening yang ada disekitar paper disc selanjutnya dilakukan pengukuran menggunakan jangka sorong.

Alat dan bahan yang digunakan dalam penelitian ini sebagai berikut:

a. Alat

Alat yang digunakan dalam penelitian ini yaitu cawan petri, bunsen, oven, hot plate, gelas ukur, erlenmayer, magnetik stirer, timbangan elektrik, ember almunium, mortar dan pinset, koset, perforator, nampan, jangka sorong.

b. Bahan

Bahan yang digunakan adalah daun Flacourtia rukam, biakan Eschericia coli, alkohol 70\%, aquades, NA(Nutrient Agar), almunium foil, masker, sarung tangan, tisu, cotton buddan spritus, kain kasa, kertas cakram (paper disc) dengan diameter $5,5 \mathrm{~mm}$

\section{Prosedur Penelitian}

Adapun prosedur dalam penelitian ini, terdiri atas: 1) Menyiapkan alat dan bahan; 2) Mensterilisasi alat dan bahan dengan perebusan; 3) Mensterilkan alat dan bahan menggunakan panas (oven); 4) Mensterilkan bahan menggunakan Bunsen; 5) Membuat NA; 6) Membuat sari pati daun Flacourtia rukam; dan 7) Pengujian aktivitas antibakteri.

\section{Teknik Pengumpulan Data}

Pengambilan data yaitu observasi laboratorium dengan teknik pengamatan zona hambat sari pati daun Flacourtia rukam secara langsung melalui lembar pengamatan yang diukur dengan alat jangka sorong. Zona hambat yang terbentuk merupakan zona bening yang tidak ditumbuhi bakteri lain dan dikurangkan diameter yang ditumbuhi bakteri di sekitar paper disc. Kemudian hasil pengukuran dianalisis secara kuantitatif

\section{Teknik Analisis Data}

Teknik analisis data yang digunakan dalam penelitian ini adalah kuantitatif Rumus serta pengukuran yang digunakan dapat dilihat pada Gambar 1.

Diameter zona hambatan $=$ Diameter jernih- diameter kertas

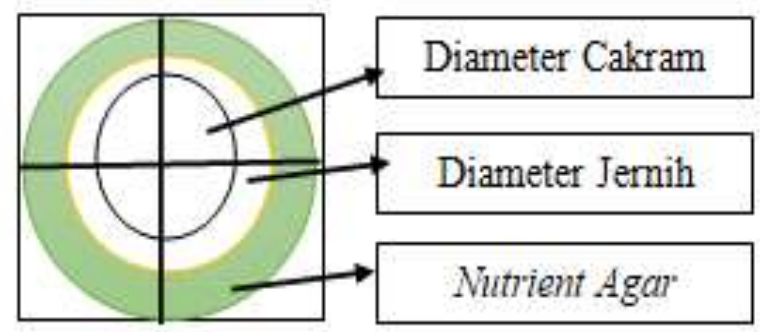

Gambar 1. Rumus dan Pengukuran Zona Hambat (Sumber: Toy, dkk, 2015) 
Setelah data didapatkan maka langkah selanjutnya dilakukan analisis. Data yang digunakan dalam penelitian ini dihitung secara manual dan data yang sudah diolah dijadikan dalam bentuk tabel, gambar, dan tulisan. Pengambilan keputusan dengan standar umum daya hambat dapat diliht pada Tabel 1.

Tabel 1. Klasifikasi Respon Hambat Pertumbuhan Bakteri

\begin{tabular}{ccc}
\hline No & Zona Hambat & Daya Hambat \\
\hline 1 & $>20 \mathrm{~mm}$ & Sangat kuat \\
2 & $10-20 \mathrm{~mm}$ & Kuat \\
3 & $5-10 \mathrm{~mm}$ & Sedang \\
4 & $<5 \mathrm{~mm}$ & Lemah \\
5 & \multicolumn{2}{c}{ Tidak ada zona hambat } \\
\hline \multicolumn{2}{l}{}
\end{tabular}

\section{HASIL DAN PEMBAHASAN}

Pada konsentrasi 4\%, 6\% dan 8\% didapatkan bahwa daun rukam mampu menghambat bakteri Escherichia colidengan kriteria sedang. Sedangakan konsentrasi $10 \%$ daun rukam mampu menghambat bakteri Escherichia colidengan kriteria kuat. Ampicilin merupakan obat antibakteri yang digunakan sebagai kontrol positif. Pada perlakuan ini dengan menggunakan $500 \mathrm{mg}$, hasil yang didapat bahwasanya ampicilin mampu menghambat bakteri Escherichia colidengan kriteria kuat. Sholekhudin (2014) obat kimia yang beredaran dipasaran untuk mengatasi penyakit diare yaitu ampicillin dengan dosis $500 \mathrm{gr}$.

Pada konsentrasi 4\% rata-rata zona hambat yang dimiliki sebesar 7,02 mm. Pada konsentrasi 6\% rata-rata zona hambat sebesar 7,92 $\mathrm{mm}$, dan untuk konsentrasi $8 \%$ sebesar 9,36 mm. Serta konsentrasi $10 \%$ rata-rata zona hambat sebesar 11,58 $\mathrm{mm}$. Jadi dapat disimpulkan bahwa semakin besar konsentrasi semakin besar pula zona hambat yang didapat. Hal ini dapat dilihat dari Gambar 2.

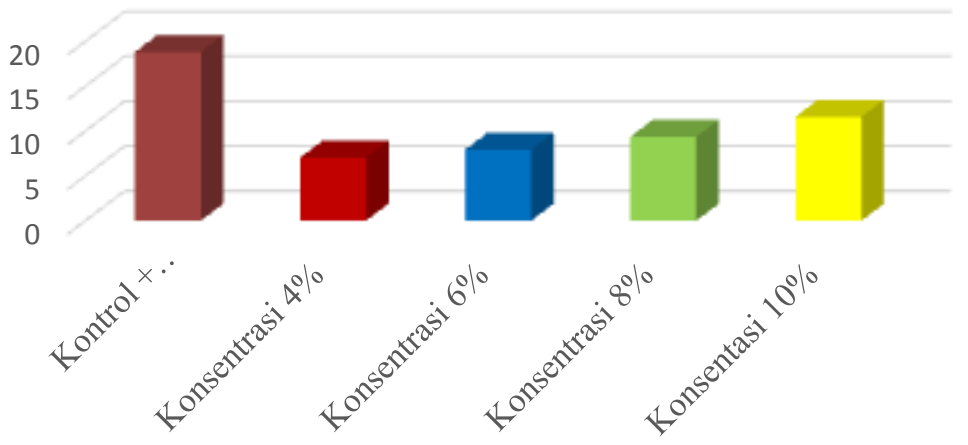

Gambar 2. Grafik Zona Hambat Pada Setiap Konsentrasi

Hasil penelitian menggunakan ampicilin 500 mg sebagai kontrol positif didapat bahwa ampicilin mempunyai zona hambat yang kuat dibandingkan daunrukam. Hal tersebut dikarenakan ampicilin merupakan salah satu contoh antibiotik golongan aminopinisilin yang memiliki aktivitas terhadap mikroorganisme seperti Escherichia coli (Kemenkes RI, Nomor 2406 Tahun 2011). Ampicilin juga merupakan obat yang memiliki senyawa golongan beta lactam yang dijadikan sebagai antibiotik dalam mencegah berbagai infeksi saluran pernapasan, ,msaluran cerna, dan saluran kemih (Kemenkes RI, Nomor 2406 Tahun 2011).

Ampicilin bekerja dengan cara memecah enzim dinding sel serta menghambat langkah terakhir dalam sintesis peptidoglikan yaitu heteroplimer yang 
memberikan stabilitas mekanik pada dinding sel bakteri. Karena sintesis dinding sel terganggu maka bakteri tidak dapat mengatasi adanya perbedaan tekanan osmosa diluar dan di dalam sel. Hal tersebut yang nantinya akan menyebabkan bakteri mati.

Ampicilin merupakan salah satu obat kimia yang sering ditemukan dalam pengobatan diberbagai masyarakat. Namun penggunaan antibiotik memiliki dampak negatif bila penggunaanya secara tidak rasional, terlalu sering, dan penggunaan berlebihan serta penggunaan yang secara terus menerus dapat mengakibatkan adanya resistensi mikroorganisme (Pratiwi, 2017). Sehingga tanaman obat tradisional dapat dijadikan suatu alternatif maupun pengganti dalam pengobatan karena memiliki efek samping yang rendah. Penggunaan obat tradisional tidak memerlukan biaya yang mahal, mudah dan memiliki manfaat yang lebih terasa atau dapat dikatakan manjur (Jennifer \& Saptutyningsih, 2015). Hal ini dapat dilihat dengan adanya penelitian sari pati daun rukam yang dijadikan sebagai obat tradisional penghambat bakteri Eschericia coli.

Hasil yang didapat selama penelitian bahwa rukam memiliki zona hambat terhadap Eschericia coli. Zona hambat yang paling tinggi diantara 4 konsentrasi sari pati daun rukam yaitu pada konsentrasi 10\%. Hal tersebut dikarenakan lebih tingginya kandungan metabolit sekunder sari pati daun rukam yaitu sebanyak $10 \mathrm{gr}$. Daun rukam memiliki tekstur daun yang sangat keras. Daun rukam yang telah dijadikan sari pati akan bewarna merah kehitaman. Warna merah kehitaman pada daun rukam memberikan warna pekat pada zona hambat. Sehingga zona hambat yang dihasilkan tidak bewarna putih murni melainkan putih yang bercampur senyawa kimia pada daun rukam yang sedang berdifusi.

Daun rukam diketahui mempunyai senyawa kimia berupa alkaloid, flavonoid, fenolik, dan saponin (Fitri, dkk, 2016). Senyawa flavonoid pada rukam menunjukan aktivitas antibakteri dengan merusak dinding sel dan membran sel bakteri (Yunikawati, dkk, 2013). Kemudian senyawa alkaloid akan mengganggu komponen penyusun peptidoglikan pada sel bakteri sehingga lapisan dinding tidak terbentuk secara utuh. Senyawa saponin akan menyebabkan kebocoran protein dan enzim dari dalam sel serta menurunkan tegangan permukaan dinding sel bakteri dan merusak permeabilitas membran. Senyawa saponin akan berdifusi melalui membran luar dan dinding sel yang rentan kemudian mengikat membran sitoplasma sehingga mengganggu dan mengurangi kestabilan membran sel. Hal ini yang menyebabkan sitoplasma bocor dan keluar dari sel (Dalimunthe \& Rachmawan, 2017). Sehingga senyawa fenol akan mengganggu struktur protein yang nantiya akan menyebabkan aktivitas biologis rusak sehingga tidak dapat melakukan fungsinya (Saraswati, 2011).

\section{SIMPULAN}

Sari pati daun rukam (Flacourtia rukam) memilki aktifitas antibakteri dengan membentuk zona hambat bagi Eschericia coli. Klasifikasi respon hambat pertumbuhan bakterirukam dikatagorikan memiliki zona hambat yang kuat karena, rata-rata zona hambat yang didapat $10-20 \mathrm{~mm}$. Kontrol positif berupa ampicilin yang memiliki zona hambat lebih besar dibandingkan rukam. Hal ini dikatagorikan bahwa senyawa pada ampicilin memiliki zona hambat yang kuat yaitu sekitar 10-20 mm.

\section{REFERENSI}

Buku Saku Petugas Kesehatan. (2011). Departemen Kesehatan RI Direktorat Jenderal Pengendalian Penyakit dan Penyehatan Lingkungan. Jakarta: Ditjen PP \& PL. 
Dalimunthe, I. C \& Rachmawan, A. (2017). Prospek Pemanfaatan Metabolit Sekunder Tumbuhan Sebagai Pestisida Nabati Untuk Pengendalian Patogen Pada Tanaman Karet. Warta Perkaretan, 36, (1), 15-28.

Dinas Kesehatan. (2017). Profil Kesehatan Kabupaten Musirawas Utara. Muara Rupit: Dinkes Kabupaten Musirawas Utara.

Fitri, N., Ulandari, S.A., Waldani, O.I., Noviyani, S., \& Allwar. (2016). Uji Aktivitas Antioksidan Ekstrak Daun Rukem (Flacourtia rukam) Dengan Metode DPPH (1,1-Difenil-2-Pkrilhidrazil), HKI: Prosiding Seminar Nasional Kimia-Lombok.

Hidayat, M.N., Hifiza, A., \& Asmar, I. (2013). Uji Daya Hambat Rebusan Herbal (Bawang Putih, Daun Sirih, dan Kayu Manis) Terhadap Pertumbuhan Bacillus subtilis dan Escherichia coli. Jurnal Industri Peternakan, 1, (1), 13-23

Ikram, E.H.K., K.H. Eng, A.M.M. Jalil, A. Ismail, S. Idris, A. Azlam, H.S.M. Nazri, ～N.A.M. Diton, \& R.A.M. Mokhtar. (2009). Antioxidant capasity and total phenolic content of Malaysian underutilized fruit. Jurnal Food Compos. Anal, 22(5), 388-393.

Jennifer, H., \& Saptutyningsih. (2015). Preferensi Individu Terhadap Pengobatan Tradisional Di Indonesia. Jurnal Ekonomi dan Studi Pembangunan, 16, (1), 2641.

Korompis, F., Tjitrosantoso, H., Goenawi, R.L. (2013). Studi Penggunaan Obat Pada Penderita Diare Akut di Instalasi Rawat Inap Blu RSUP Prof. Dr. R. D. Kandou Manado Periode Januari-Juni 2012. Jurnal Ilmiah Farmasi, 2, (1), 2302-2493.

Peraturan Menteri Kesehatan RI Nomor 2406. (2011). Pedoman Umum Penggunaan Antibiotik. Jakarta: Kementeria Kesehatan RI.

Ehra. (2013). Pokja Sabitasi Kabupaten Musirawas Program Percepatan Pembangunan Sanitasi Permukiman. Kabupaten Musirawas: Pokja sanitasi.

Mafazah, L. (2013). Ketersediaan Sarana Sanitasi Dasar, Personal Hygiene Ibu dan Kejadian Diare. Jurnal Kesehatan Masyarakat, 8, (2), 176-182.

Ningrum, R., Purwanti, \& E., Sukarsono. (2016). Identifikasi Senyawa Alkaloid Dari Batang Karamunting (Rhodomyrtus tomentosa) Sebagai Bahan Ajar Biologi Untuk SMA Kelas X. Jurnal Pendidikan Biologi Indonesia, 2, (3), 231-236

Pratiwi, H. R. (2017). Mekanisme Pertahanan Bakteri Patogen Terhadap Antibiotik. Jurnal Pro-Life, 4, (3), 418-429.

Rencana Aksi Program Pengendalian Penyakit dan Penyehatan Lingkungan Tahun 2015-2019. (2015). Direktorat Jenderal Pengendalian Penyakit dan Peyehatan Lingkungan. Jakarta: Ditjen PP \& PL

Saraswati, D. (2011). Pengaruh Konsentrasi Ekstrak Daun Sirih Terhadap Daya Hambat Escherichia coli. Jurnal Health \& Sport, 3, (2), 285-362.

Selviana, dan Widowati, W. 2015. Determinan Terjadinya Penyakit Diare Akut Pada Balita Di Wilayah Pesisir. Jurnal Vokasi Kesehatan, 1 (6), 161-168

Sembiring, \& Nurhayati. (2013). Sistem Pakar Diagnosa Penyakit Diare (Gastroentiritis). Jurnal KAPUTAMA, 6, (2), 10-19.

Sholekhudin, M. (2014). Obat Sehari-hari. Jakarta: Gramedia.

Toy, S. S. T. Lampus, S. B. \& Hutagalung, P. S. B. (2015). Uji Daya Hambat Ekstrak Rumput Laut Gracilaria spTerhadap Pertumbuhan Bakteri Staphylococcus aureus. Jurnal e-GiGi, 3 (1), 153-159

Woko, Y.P. (2018). Obat Tradisional Desa Sumber Harta Kabupaten Musirawas. Wawancara Desmi Viana Putri. 2 Desember Pukul 17.15.

Yunikawati, A.P.M., Besung, K.N., \& Mahatmi, H. (2013). Efektifitas Perasan Daun Srikaya Terhadap Daya Hambat Pertumbuhan Escherichia coli. Indonesia Medicus Veterinus, 2, (2), 170-179. 